\title{
Loss of fumarylacetoacetate hydrolase is responsible for the neonatal hepatic dysfunction phenotype of lethal albino mice
}

\author{
Markus Grompe, ${ }^{1,2,5}$ Muhsen Al-Dhalimy, ${ }^{1}$ Milton Finegold, ${ }^{3}$ Ching-Nan Ou, ${ }^{2}$ Terry Burlingame, ${ }^{1}$ \\ Nancy G. Kennaway, ${ }^{1}$ and Philippe Soriano ${ }^{4}$ \\ ${ }^{1}$ Department of Medical and Molecular Genetics and ${ }^{2}$ Pediatrics, Oregon Health Sciences University, Portland Oregon \\ 97201 USA; $^{3}$ Department of Pathology, Texas Children's Hospital, Houston, Texas $77030-2399$ USA; ${ }^{4}$ Program in Molecular \\ Medicine, Fred Hutchinson Cancer Research Center, Seattle, Washington 98104 USA
}

\begin{abstract}
Mice homozygous for the $\mathrm{c}^{14 \mathrm{Cos}}$ albino deletion die as neonates as a result of liver dysfunction. Previous mapping studies have associated this defect with a $310-\mathrm{kb}$ fragment encoding the hepatocyte-specific developmental regulation locus (alf/hsdr-1). The gene encoding fumarylacetoacetate hydrolase (Fah), a metabolic enzyme that catalyzes the last step of tyrosine catabolism, also maps to the same deletion interval. To test whether the neonatal defects found in the albino deletion mutants are attributable to loss of Fah, and not to another gene mapping to the deletion, we have generated Fah mutant mice by gene targeting in embryonic stem cells. Fah-deficient mice die within $12 \mathrm{hr}$ after birth from hypoglycemia and liver dysfunction. In addition, the same pattern of altered liver mRNA expression found in the albino deletion mutants was also found in affected animals. We conclude that the neonatal lethal and liver dysfunction phenotype of the alf/hsdr-1 deletion is entirely attributable to loss of Fah.
\end{abstract}

[Key Words: Lethal albino deletion; tyrosinemia type I; gene targeting]

Received September 15, 1993; revised version accepted October 14, 1993.

The $\mathrm{c}^{\mathrm{14CoS}}$ albino mouse is one of a series of mutant mice bearing large overlapping X-ray-induced deletions of chromosome 7 (Russell et al. 1979). The albino deletions contain several loci involved in development and are all estimated to be several megabases in size. Mice homozygous for various albino deletions have different phenotypes ranging from developmental arrest in utero to neonatal death as a result of liver dysfunction. Mice homozygous for the deletions $\mathrm{c}^{65 \mathrm{~Kb}}, \mathrm{c}^{112 \mathrm{~Kb}}, \mathrm{c}^{3 \mathrm{H}}$, and $\mathrm{c}^{14 \mathrm{CoS}}$ die within a few hours after birth and display abnormal or no expression of many hepatic enzymes /GluecksohnWaelsch 1979; Russell et al. 1979; Rinchik and Russell 1990). These include tyrosine aminotransferase (TAT) (Schmid et al. 1985), glucose-6 phosphatase (G-6P) (Gluecksohn-Waelsch 1979), glutamine synthetase (GS) (Gluecksohn-Waelsch 1979), phosphoenolpyruvate carboxykinase (PEPCK) (Loose et al. 1986), aldolase B, albumin, $\alpha$-fetoprotein (Sala-Trepat et al. 1985), urea cycle enzymes /Gluecksohn-Waelsch et al. 1974; Sala-Trepat et al. 1985; Schmid et al. 1985; Loose et al. 1986; Morris et al. 1988), several liver transcription factors (McKnight et al. 1989; Gonzalez et al. 1990; Ruppert et al. 1990;

${ }^{5}$ Corresponding author.
Tönjes et al. 1992), and two anonymous transcripts X1 and X2 (Ruppert et al. 1990). Reduced expression is associated with lower mRNA levels for TAT, PEPCK, the urea cycle genes, and aldolase $B$, but normal steady-state mRNA levels are found for the serum proteins (SalaTrepat et al. 1985). Electron microscopy examination reveals structural abnormalities in both liver and kidney of these mice (Gluecksohn-Waelsch 1979). Many of the enzymes affected play a role in glucose homeostasis, suggesting hypoglycemia as the cause of death in the newborn mice (Gluecksohn-Waelsch 1979). Several, although not all, of the genes involved are normally inducible by glucocorticoids and/or cAMP, but this does not occur in the albino deletion mice (Schmid et al. 1985). This observation has led to the hypothesis that a regulatory liver gene [hepatocyte-specific developmental regulation locus (hsdr-1)] is localized within the deletion (McKnight et al. 1989). This locus has also been termed alf (albino lethal deletion factor) (Ruppert et al. 1990). In contrast to the decreased expression of some cAMP-responsive liver-specific mRNAs, transcripts that are induced by DNA damage in cells, such as CHOP, or that are involved in detoxification, such as $\mathrm{NAD}(\mathrm{P}) \mathrm{H}$ :oxidoreductase (NMO-1), are elevated in the livers of $\mathrm{c}^{14 \mathrm{CoS}}$ deletion mice (Fornace et al. 1989; Petersen et al. 1989). 
Detailed mapping of the deletion interval in the $\mathrm{c}^{14 \mathrm{CoS}}$ mice has identified a $310-\mathrm{kb}$ fragment within which the alf/hsdr-1 gene must be localized (Niswander et al. 1991; Kelsey et al. 1992). Recently, two groups reported the isolation of a liver-specific cDNA from the $310-\mathrm{kb}$ deletion interval encoding fumarylacetoacetate (FAA) hydrolase (Fah, EC 3.7.1.2) (Klebig et al. 1992; Ruppert et al. 1992). Fah catalyzes the last step in tyrosine catabolism, the conversion of FAA to acetoacetate and fumarate (see Fig. 1) (Knox and Edwards 1955; Goldsmith and Laberge 1989|. In addition, the timing and localization of Fah expression in the mouse fits the pattern predicted for alf/hsdr-1 (Ruppert et al. 1992), and some of the phenotypic abnormalities seen in the alf/hsdr-1 deletion can be reproduced in primary liver cells stressed with homogentisic acid (Ruppert et al. 1992). These observations suggest, but do not prove, that Fah is identical to alf/ hsdr-1.

In humans, deficiency of FAA hydrolase causes hereditary tyrosinemia type I (HT1), a severe, autosomal recessive inborn error of metabolism (Lindblad et al. 1977; Tanguay et al. 1984). Affected children develop liver failure in the first few months after birth and frequently die within a year (Kvittingen 1986; Goldsmith and Laberge

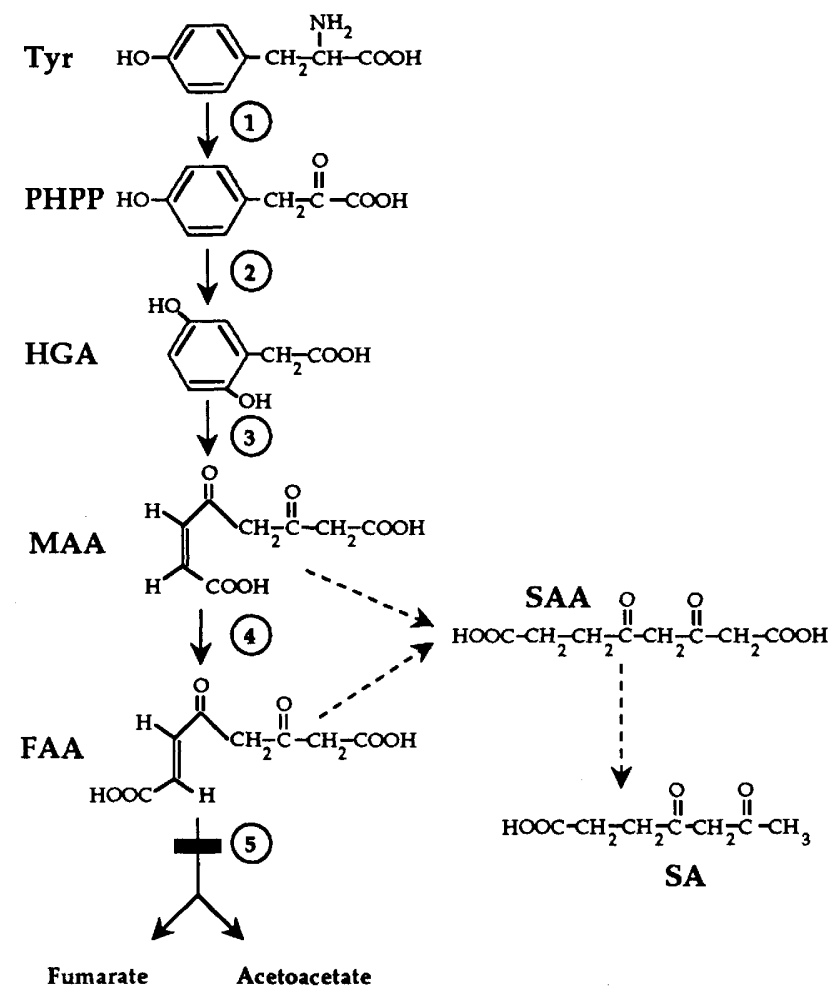

Figure 1. Tyrosine degradation pathway. The principal metabolites in the pathway are tyrosine (Tyr), p-OH-phenylpyruvate (PHPP), homogentisic acid (HGA), maleylacetoacetate (MAA), fumarylacetoacetate (FAA), succinylacetoacetate (SAA), and succinylacetone (SA). The enzymes are TAT (1), p-OH-phenylpyruvate dioxygenase (2), homogentisic acid oxidase (3), MAA isomerase (4), and FAA hydrolase (5). The broken lines indicate metabolic steps, in which the exact enzymes/mechanisms involved are not known.
1989|. Additional features of the disorder include renal tubular dysfunction, cardiomyopathy (Edwards et al. 1987), and severe neurologic crisis (Mitchell et al. 1990). Hepatomas and, in later stages, hepatocellular carcinomas are a very frequent complication (Russo and $O^{\prime}$ Regan $1990 \mid$. Biochemically, the disease is characterized by the accumulation of multiple abnormal compounds in blood and urine: tyrosine, methionine, tyrosine metabolites, and succinylacetone (SA) (Goldsmith and Laberge 1989). SA is the diagnostic metabolite in Fah deficiency in humans and is not found in urine of healthy individuals. It presumably derives from the reduction of maleylacetoacetate (MAA) and FAA in vivo (see Fig. 1). It has been speculated, but not proven, that MAA and FAA are primarily responsible for much of the local tissue damage leading to necrosis of hepatocytes and other cells (Lindblad et al. 1977; Goldsmith and Laberge 1989|.

Several remarkable secondary biochemical alterations have been described in human $\mathrm{HT}$, including the inhibition of $\delta$-aminolevulinic acid dehydratase by SA (Sassa and Kappas 1982, 1983), elevations in serum $\alpha$-fetoprotein levels, and decreased levels of several hepatic enzymes, especially TAT. Evidence for depletion of intracellular reducing compounds, such as low levels of glutathione in red cells and a deficit in cysteine, has been found (Stoner et al. 1984).

Here, we report the derivation of mice deficient in Fah by use of targeted gene disruption in embryonic stem (ES) cells to determine the relationship between the alf/ $h s d r-1$ locus and this metabolic enzyme. Possible explanations for the observed phenotype and the differences between murine and human Fah deficiency are discussed.

\section{Results}

Derivation of $\mathrm{Fah}^{-}$mice

The Fah gene was disrupted with a replacement vector (pD10), in which a neo expression cassette was inserted into a unique SphI site in exon 5 of the gene (Fig. 2A). This construct had $\sim 5 \mathrm{~kb}$ of homology $5^{\prime}$ and $\sim 1.5 \mathrm{~kb} 3^{\prime}$ to the insertion, respectively. Because exon 5 was found to be 91 bp long (data not shown), a neo insertion should lead to a frameshift and a null allele, even if the targeted exon was skipped during splicing. A herpes simplex virus thymidine kinase (HSV TK) expression cassette was included at the $3^{\prime}$ end of the homology to select against nontargeted insertions. After linearization, the replacement vector was electroporated into ES cells and doubleselection with G418 and gancyclovir, was carried out. Doubly resistant clones [14/120 $(\sim 1 / 8)]$ analyzed by Southern blot with probe A (Fig. 2B) showed the 1.4-kb increase in size expected for a targeting event. The Southern blots were also probed with neo to verify the presence of only one copy of the replacement vector in the cells (Fig. 2B). A third probe derived from the region $5^{\prime}$ to the homology was used to demonstrate that the $5^{\prime}$ flank of the disrupted locus had the expected structure (data not shown). Five targeted ES clones were injected into $\mathrm{C} 57 \mathrm{BL} / 6 \mathrm{~J}$ blastocysts, and two gave rise to germ- 
A

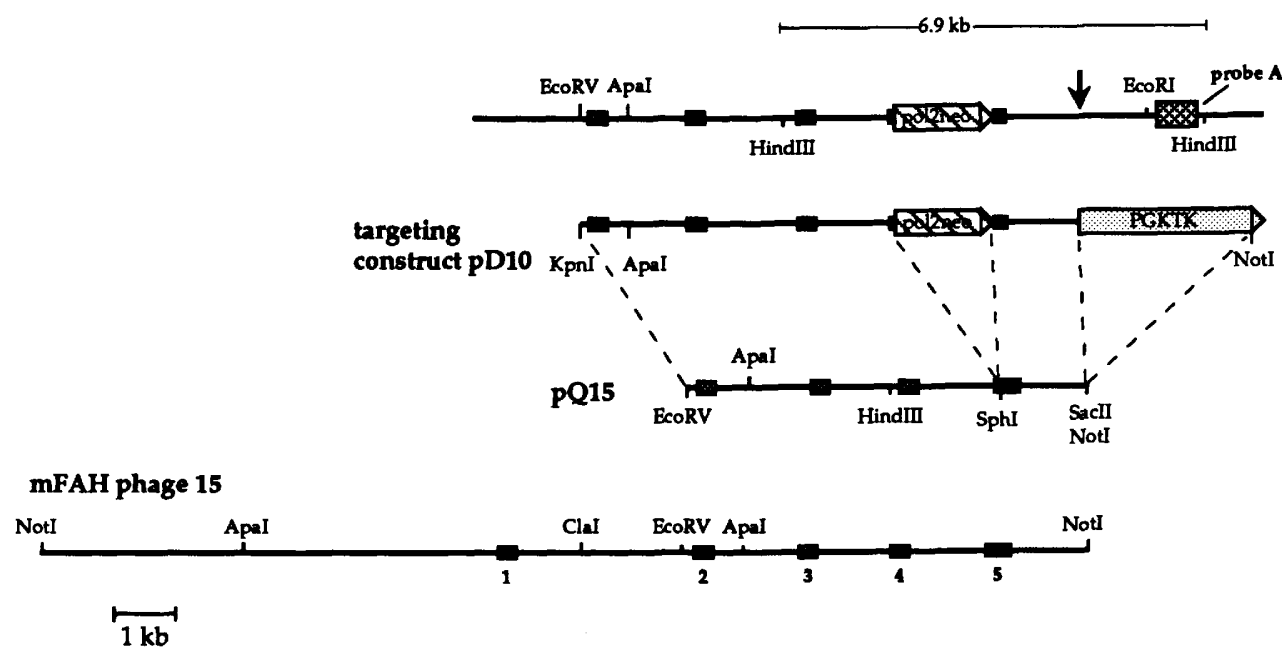

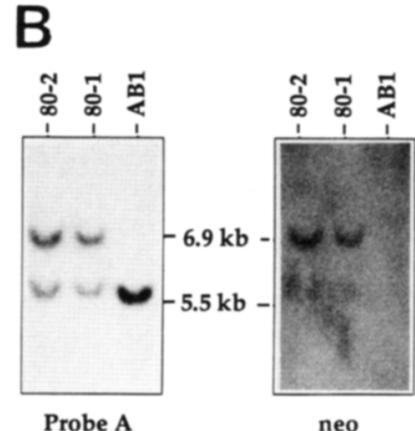

Probe A

neo

Figure 2. Targeted disruption of the Fah gene. $(A)$ The structure of mFah phage 15 from which the targeting construct was derived is shown at the bottom. Exons are indicated by hatched boxes. pQ15 is a plasmid clone, containing a 6.5 -kb fragment of the phage. A neo (pol2neo) and HSV TK expression cassette were cloned into the SphI and SacII sites of this plasmid, respectively, to yield the replacement vector pD10. A schematic representation of the expected structure of the targeted Fah locus is shown at the top. The arrow marks the 3' end of the homology in the replacement vector. The probe (A) used for Southern blots is shown as a crosshatched box. $(B)$ Southern blot of HindIII-digested DNA from a control (AB1) and two founder heterozygotes $(80-1$ and 80-2). (Left) Probe A was used; (right) the same blot was reprobed with neo. The fragment sizes are indicated in the middle. The heterozygotes show the expected increase in size of the cognate band by $1.4 \mathrm{~kb}$. Only the larger band hybridizes to neo.

line chimeras, from which we established the mutant strains $\mathrm{Fah}^{\mathrm{\Delta exon} 5}$-1 and Fah ${ }^{\mathrm{\Delta exon} 5}$-2. All results discussed below were identical for both strains and independent of the genetic background (129Sv or hybrid 129Sv-C57BL/ $6 \mathrm{~J})$.

\section{Fah ${ }^{\text {sexon } 5}$ homozygotes die in the neonatal period}

$\mathrm{Fah}^{\mathrm{\Delta exon} 5}$ heterozygotes were bred, and their offspring were analyzed. No obvious differences in morphology or size were noted immediately after birth, and all pups appeared vigorous and healthy at first. In most litters, however, one to three dead pups were found after 6-12 $\mathrm{hr}$. Southern blot analysis of these dead animals revealed that they were all Fah ${ }^{\mathrm{Aexon} 5}$ homozygotes. Because there were no obvious morphologic parameters for the homozygotes before their death, a simple PCR-based test was developed to determine genotype (data not shown). No Fah ${ }^{\Delta e x o n 5}$ homozygotes were observed to survive past $24 \mathrm{hr}$ after birth.

For further analysis of the phenotype, all pups were sacrificed within $12 \mathrm{hr}$ after birth, dissected, and genotyped by PCR by use of tail DNA. Among 221 pups, 70 were homozygous wild type (32\%), 106 were heterozygous $(48 \%)$, and 45 were Fah $^{\text {Aexon5 }}$ homozygous $(20 \%)$. Thus, slightly fewer than the expected $25 \%$ of animals were homozygotes. This distortion could be explained by decreased intrauterine viability, but more likely is caused by missing some animals that died early postnatally and were eaten. No statistically significant weight differences were detected among the three different genotypes (Table 1).

Homozygous Fah ${ }^{\text {גexon5 }}$ mice have multiple biochemical abnormalities

Several biochemical parameters were analyzed in the $\mathrm{Fah}^{\mathrm{e} e x o n 5}$ strain to compare the biochemical phenotype with that of $c^{14 \operatorname{CoS}}$ albino deletion mice. First, Fah measurement in liver revealed a complete absence of enzyme activity in $\mathrm{Fah}^{\Delta \mathrm{exon} 5}$ homozygotes. Heterozygotes had approximately half the activity $(10.8 \pm 2.25 \mu \mathrm{mole} / \mathrm{mg}$ per $\mathrm{min})$ of wild-type littermates $(20.1 \pm 1.9 \mu \mathrm{mole} / \mathrm{mg}$ per min). It therefore appears that the Fah ${ }^{\Delta e^{2} \text { on5 }}$ mutation represents a null allele.

Blood glucose was measured during two different time intervals: immediately after birth or $>6 \mathrm{hr}$ after birth. No significant differences between the three genotypes were observed immediately after birth. Homozygotes, however, had markedly decreased blood glucose levels, if they were sacrificed $>6 \mathrm{hr}$ postnatally (Table 1), indicating a gradual onset of hypoglycemia during the first few hr of life. Similar decreases to less than half of normal blood glucose level have also been observed in $\mathrm{c}^{14 \mathrm{Cos}}$ deletion homozygotes (Gluecksohn-Waelsch 1979).

Fah is primarily expressed in liver and kidney in both man and mouse; therefore, blood chemistries that correlate with function of these organs were of interest. Two parameters were determined. The plasma levels of the liver enzyme aspartate aminotransferase (AST), which 
Table 1. Biochemical parameters in the Fah ${ }^{\text {גexon5 }}$ strain

\begin{tabular}{|c|c|c|c|c|}
\hline & Unit & $\mathrm{Wt} / \mathrm{wt}$ & $\mathrm{Wt} / \Delta$ exon5 & $\Delta$ Exon $5 / \Delta$ exon 5 \\
\hline Birth weight & grams & $1.43 \pm 0.29(5)$ & $1.30 \pm 0.25(8)$ & $1.15 \pm 0.12(4)$ \\
\hline Glucose $(6-12 \mathrm{hr})$ & $\mathrm{mg} / \mathrm{dl}$ & $63 \pm 22$ & $76 \pm 24 \quad(10)$ & $32 \pm 9$ \\
\hline AST & U/liter & $164 \pm 66 \quad\{17\}$ & $194 \pm 124(24)$ & $1148 \pm 1211(10)$ \\
\hline Creatinine & $\mathrm{mg} / \mathrm{dl}$ & $1.0 \pm 0.2$ & $1.0 \pm 0.2 \quad(6)$ & $1.5 \pm 0.1$ \\
\hline Glutamine & $\mu$ mole/liter & $830 \pm 92$ & $856 \pm 97$ & $847 \pm 60$ \\
\hline Citrulline & $\mu$ mole/liter & $32 \pm 7$ & $37 \pm 29$ & $127 \pm 31$ \\
\hline Methionine & $\mu$ mole/liter & $139 \pm 35$ & $128 \pm 28$ & $328 \pm 50$ \\
\hline Isoleucine & $\mu \mathrm{mole} / \mathrm{liter}$ & $136 \pm 13$ & $118 \pm 6$ & $94 \pm 20$ \\
\hline Tyrosine & $\mu$ mole/liter & $147 \pm 42$ & $174 \pm 46$ & $195 \pm 26$ \\
\hline Phenylalanine & $\mu \mathrm{mole} /$ liter & $116 \pm 27$ & $121 \pm 22$ & $382 \pm 55$ \\
\hline Ornithine & $\mu \mathrm{mole} /$ liter & $132 \pm 15$ & $122 \pm 9$ & $235 \pm 2$ \\
\hline Arginine & $\mu$ mole/liter & $178 \pm 35$ & $202 \pm 41$ & (3) \\
\hline
\end{tabular}

The parameters measured and the units in which they are expressed are at left. The values \pm S.D. are given for each genotype, with the numbers in parentheses indicating the number of animals analyzed.

correlates with hepatocellular damage (leakage of this hepatic enzyme into the circulation), was measured and found to be markedly elevated in the homozygotes, with values as high as $3840 \mathrm{U} /$ liter (see Table 1). Some homozygotes had levels within the normal range, which was likely related to the time after birth at which the blood sample was taken. Severe hepatocellular damage may be an end-stage event. The plasma creatinine levels, a measure of renal function, were also elevated in the homozygotes (Table 1).

Quantitative plasma amino acid analysis was carried out on several litters. Abnormal amino acid values are listed in Table 1. Interestingly and in contrast to human Fah deficiency, no elevations in the plasma tyrosine levels were detected in the affected animals. Phenylalanine and methionine levels, however, were increased about threefold in homozygotes. Most significant, however, were the abnormalities in arginine, citrulline, and ornithine, amino acids that participate in the urea cycle. The elevations in citrulline and ornithine were mild (only two- to threefold), but arginine was nondetectable in Fah-deficient pups. The abnormalities in urea cycle-related amino acids again are in contrast to the human HT1 phenotype, in which no such disturbances have been reported.

SA is the hallmark metabolite of human tyrosinemia and is derived directly from FAA, the substrate of Fah (see Fig. 1). To detect this compound, organic acids were extracted from the livers of animals and analyzed quantitatively by gas chromatography and mass spectrometry; but even with this highly sensitive method, no SA was detectable in liver extracts in Fah-deficient homozygotes. This result was consistent with a previous report, in which SA levels in liver were measured in homozygous $\mathrm{c}^{14 \mathrm{Cos}}$ mice and found not to be elevated (Collins et al. 1992). The relevance of this finding, however, was questionable, because it has been shown in human HT1 patients, that SA is often not elevated in liver, whereas it is easily detectable in plasma and urine in the same patient (Tuchman et al. 1985). For this reason, SA analysis was also carried out in plasma. SA was clearly detectable in the plasma of $\Delta$ exon5 homozygotes at a level of $\sim 0.5$ $\mu \mathrm{g} / \mathrm{ml}$, whereas it was undetectable in unaffected littermates. SA levels in human HTl patients are of the same order of magnitude $(0.3-20 \mu \mathrm{g} / \mathrm{ml})$ (Grenier and Lescault 1985).

\section{Electron microscopy examination shows disruption of the endoplasmic reticulum}

Because no consistent differences in the histological appearance of livers from homozygous deficient, heterozygous, and wild-type mice could be found by use of light microscopy, an electron microscopy study was undertaken. This revealed extensive depletion of glycogen from the cytoplasm with corresponding reduction in size of the hepatocytes (Fig. 3B). In addition, the usual parallel arrays of rough endoplasmic reticulum found in the immature hepatocytes of wild-type mice (Fig. 3A) were disrupted in the homozygous Fah-deficient animals. The rough endoplasmic reticulum that remained was scattered widely within the cells. Some focal vesiculation of the endoplasmic reticulum was found in a few hepatocytes. These alterations are similar to those observed by Gluecksohn-Waelsch (1979) in the lethal albino mouse.

Fah mutant animals show the pattern of $m R N A$ abnormalities seen in lethal albino mice

The deletion of the alf/hsdr-1 locus in albino mutant mice leads to characteristic alterations of the expression pattern of certain mRNAs in the livers of homozygous animals. The steady-state levels of some mRNAs, most notably those inducible by cAMP, are decreased. Other transcripts, especially some mRNAs inducible by DNA damage, are present in increased amounts. Yet another group of genes is not affected by the alf/hsdr-1 deletion. We determined the mRNA levels of several examples of these groups by Northern blot analysis (Fig. 4).

In all cases, the expression pattern of the Fah ${ }^{\text {exons }}$ mice was identical to that reported for mice deleted at the alf/hsdr-1 locus. No detectable Fah mRNA was ob- 

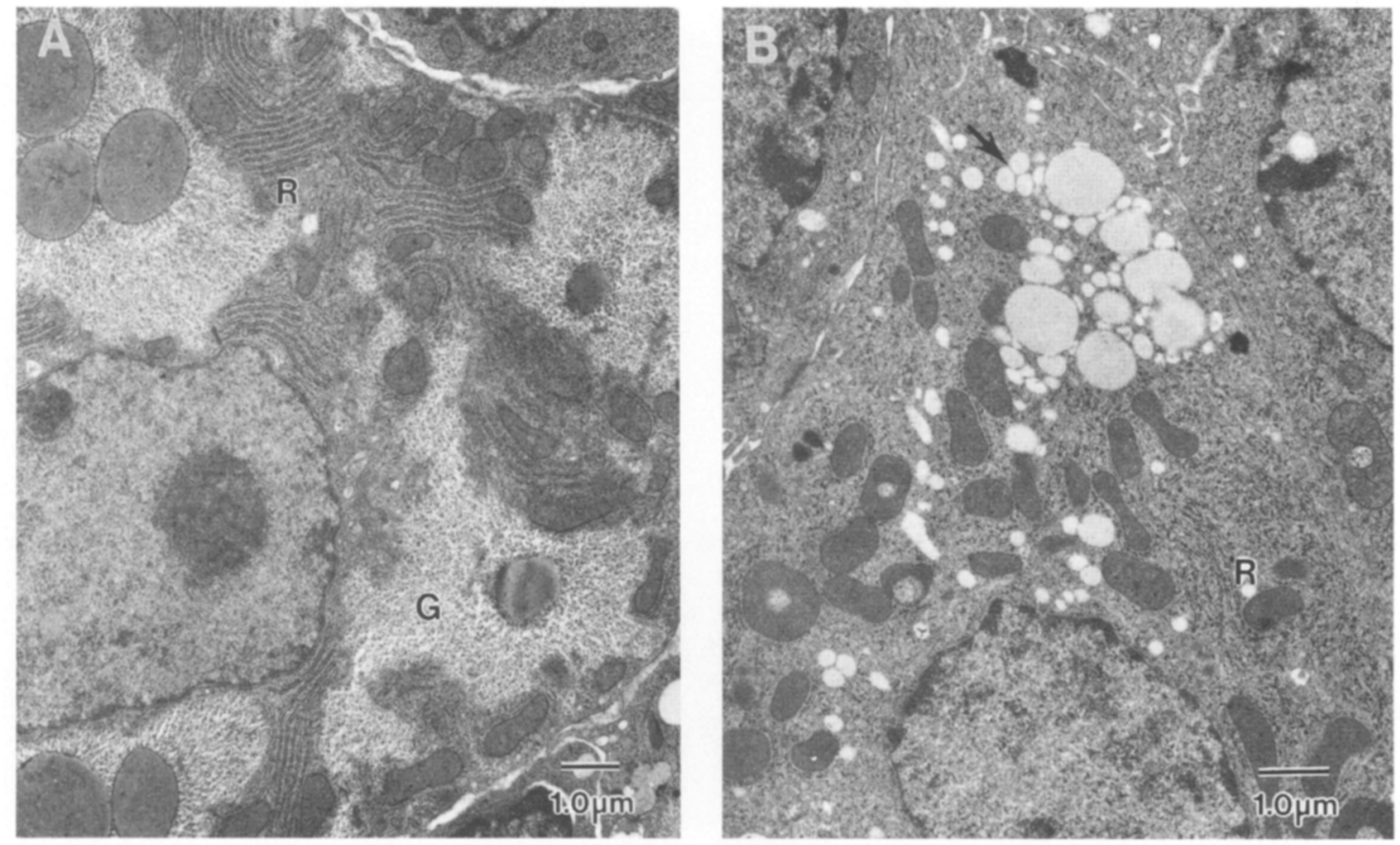

Figure 3. Liver electron microscopy. (A) Liver ultrastructure, 1-day-old control mouse, 10,500×. The hepatocytes are large and replete with glycogen $(G)$ that is responsible for the pale appearance of the cytoplasm and apparent paucity of organelles. Multiple stacks or parallel arrays of rough endoplasmic reticulum (R) are characteristic of normal, immature hepatocytes. $(B)$ Liver of homozygous $\Delta^{\text {exon}} 5$ 1-day-old mouse, $9000 \times$. Hepatocytes are small with reduced quantities of glycogen and condensation of the cytoplasm. The amount of rough endoplasmic reticulum $(\mathrm{R})$ is reduced and is scattered widely. Focal vesiculation of the endoplasmic reticulum is found (arrow). There is no morphological alteration of mitochondria, nuclei, or plasma membranes. Erythropoietic cells are plentiful in both control and affected mice.

served in homozygous Fah ${ }^{\Delta e x o n 5}$ mice, confirming that the neo insertion into exon 5 has created a null allele. The mRNA levels of the cAMP-inducible genes TAT, PEPCK, and the urea cycle enzymes argininosuccinate synthetase (AS) and ornithine transcarbamylase (OTC) were all markedly decreased, whereas NMO-1 and CHOP mRNA levels were increased. The mRNA levels of albu$\min$ (data not shown), $\alpha 1$-antitrypsin $(\alpha 1$-AT), $\alpha$-fetoprotein $(\alpha \mathrm{FP}$, data not shown), ornithine aminotransferase, and tubulin were unaltered.

\section{Discussion}

The Fah gene is a candidate for the alf/hsdr-1 locus

The alf/hsdr-1 locus in the mouse has been the subject of intense investigation for many years. The generalized down-regulation of multiple liver-specific cAMP-responsive genes in several strains of albino deletion mice has led to the hypothesis that the deletions must contain a key regulatory locus involved in controlling the expression of these genes (Gluecksohn-Waelsch and DeFranco 1991). The notion of a specific regulatory defect was supported by the report that the failure of induction was limited to cAMP-responsive liver genes and was not present in genes inducible by metal ions (DeFranco et al. 1988). Over time, however, additional abnormalities were described in these mice, which were less consistent with a specific defect. Increased mRNA levels of genes inducible by DNA damage (Fornace et al. 1989) and those involved in detoxification pathways were found (Petersen et al. 1989). Decreased transcription rates were documented for genes not inducible by cAMP (Tönjes et al. 1992) and low steady-state mRNA levels were found for several liver transcription factors (McKnight et al. 1989; Gonzalez et al. 1990; Ruppert et al. 1990; Tönjes et al. 1992).

Efforts by several groups to clone the alf/hsdr-1 gene focused on utilizing the different overlapping albino deletions to narrow down the location of the gene (Niswander et al. 1991; Kelsey et al. 1992). In 1992, two groups successfully isolated the Fah gene from the $310-\mathrm{kb}$ region of overlap between different deletions, thereby raising the question whether loss of $F a h$ was the cause for the alf/hsdr-1 deletion phenotype (Klebig et al. 1992; Ruppert et al. 1992). Additional experiments made a strong case for the identity of the two loci (Ruppert et al. 1992). The $\mathrm{c}^{14 \operatorname{Cos}}$ deletion was shown to disrupt the Fah gene, and Fah is expressed primarily in liver and kidney, beginning at day 16 as had been predicted for the alf/ $h s d r-1$ gene. In addition, primary hepatocytes cultured in the presence of homogentisic acid (HGA) displayed some of the abnormalities seen in livers of $\mathrm{c}^{14 \operatorname{Cos}}$ homozygotes. Although this evidence was supportive of the 


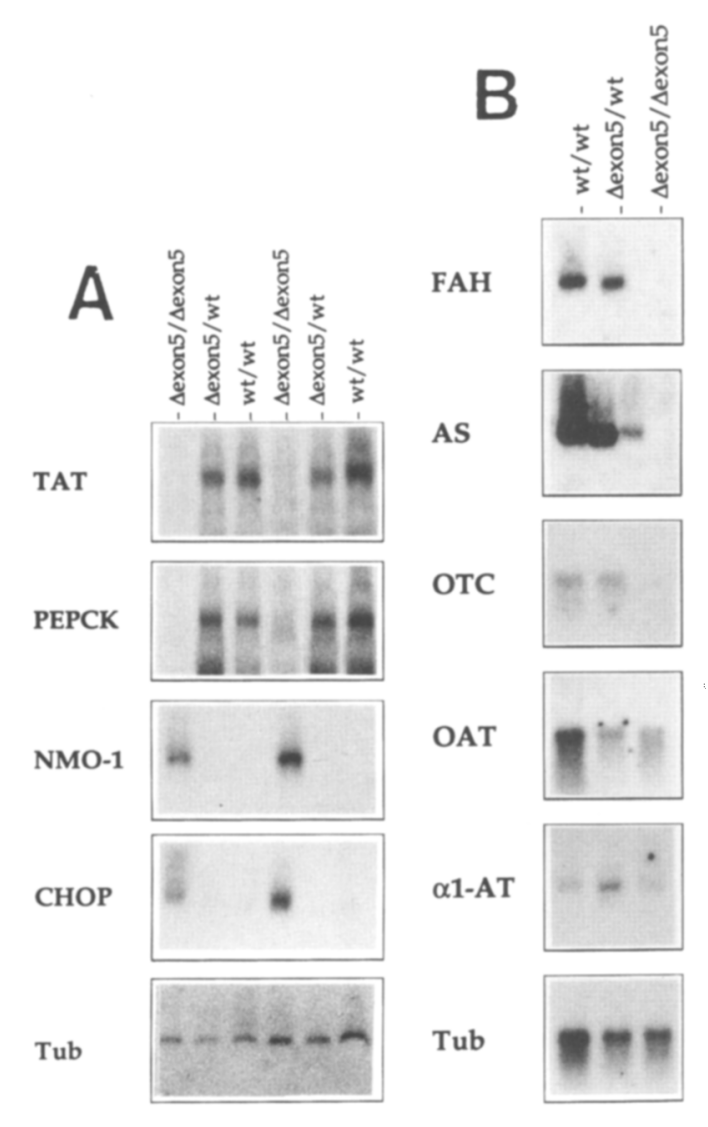

Figure 4. Northern blot analysis of liver RNA from $\Delta$ exon 5 mice. The genotype of the animals is given at the top, and the probe used is given to the left of each blot. Tubulin controls were performed on each blot by stripping and reprobing. Only one representative tubulin control is shown in each panel. $(A \mid$ Blots performed with total cellular RNA. The samples were derived from two independent litters. TAT and PEPCK mRNA levels are decreased in Fah-deficient animals compared with their normal littermates. In contrast, NMO-1 and CHOP levels are markedly increased in homozygous deficient animals. A tubulin control indicating equal loads is shown at the bottom. (B)

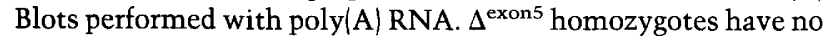
detectable Fah mRNA. The urea cycle genes AS and OTC are also reduced in the homozygotes. No differences in mRNA levels between the different genotypes were detectable for OAT, $\alpha \mathrm{l}-\mathrm{AT}$, and tubulin. The load of RNA in the homozygous wildtype lane is slightly increased in some blots (AS, OAT, Tub), but equal loads were present for heterozygotes and deficient mice in all samples.

identity of the two loci, it did not represent conclusive proof. The different alf/hsdr-1-containing deletions are all several megabases in size, and it was therefore possible that other genes within the deletions played a major role in the phenotype.

Loss of Fah results in the same phenotype as the alf/hsdr-1 deletion

To resolve this question, we have derived a strain of mice bearing a mutation in the Fah gene only. This mu- tation appears to be a null allele, as evidenced by complete absence of Fah mRNA and enzyme activity in homozygous mice. The phenotype found in Fah-deficient pups is indistinguishable from that reported for homozygous $\mathrm{c}^{14 \mathrm{CoS}}$ mice. First, it was shown that PEPCK, TAT, OTC, and AS mRNA levels are markedly decreased in Fah-deficient pups. Second, NMO-1 and CHOP levels were markedly increased. Third, albumin, $\alpha 1-\mathrm{AT}$, and $\alpha \mathrm{FP}$ were not altered. Fourth, Fah ${ }^{\Delta \mathrm{exon} 5}$ homozygotes suffer from hypoglycemia. Fifth, no alterations of liver histology were detectable in light microscopy, but electron microscopy showed abnormalities, particularly of the endoplasmic reticulum. And, finally, the biochemical phenotype, including serum amino and liver organic acids, was the same as that reported for $\mathrm{c}^{14 \cos }$ mice. Thus, there was complete concordance between the phenotypes in all parameters studied. It therefore appears that all significant aspects of the alf/hsdr-1 deletion phenotype can be explained by deficiency of Fah alone.

The X-ray-induced deletions of classic mutant mouse strains are generally large in size and likely to contain several loci. The phenotype of homozygotes is determined by which deleted locus or loci has the most severe effect in terms of viability and age of onset. The possibility that the observed phenotype is the result of multiple interacting deletions has to be taken into consideration. The Fah ${ }^{-}$mice described here are, to our knowledge, the first example in which the targeted disruption of a single gene within the deletion has been shown to be responsible for the major component of the deletion phenotype. This approach will be useful in the analysis of other large deletion mutations containing developmental genes.

\section{Possible mechanisms of the alf/hsdr-1 phenotype}

The mechanisms, by which Fah deficiency causes the rather specific abnormalities are not clear at this point. The compounds MAA and FAA, which immediately precede the metabolic block, are known to be reactive alkylating substances (R. Tanguay, pers. comm.). SA is in equilibrium with FAA and MAA (see Fig. 1) and is stable enough to accumulate and be detectable in HTl human patients. The half-lives of MAA and FAA, on the other hand, are very short, and these compounds therefore cannot be directly detected in Fah-deficient individuals. It has been suggested that the accumulation of FAA and MAA may be responsible for the abnormalities seen in $\mathrm{c}^{14 \mathrm{CoS}}$ hepatocytes (Ruppert et al. 1992; Kelsey and Schütz 1993). This hypothesis was questioned by a report demonstrating that SA was not elevated in the liver of $\mathrm{c}^{14 \mathrm{CoS}}$ mice (Collins et al. 1992). This finding implied either that FAA and MAA did not accumulate and cause the disregulation or that their conversion to SA was deficient in these mice. We have shown here that SA is present in elevated amounts in plasma of Fah-deficient mice and is of the same order of magnitude as seen in human patients. This indicates an accumulation of the toxic metabolites MAA and FAA in Fah-deficient mice and is consistent with the notion that these chemicals 
cause the alf/hsdr-1 deletion phenotype. The failure to detect SA in the liver of Fah-deficient subjects is not unique to mice as it has been reported for HT1 patients as well (Tuchman et al. 1985) and might be attributable to entrapment of available SA as a result of protein binding.

At this time one can only speculate about how the toxic metabolites exert their effect. Both MAA and FAA are predicted to react with sulfhydryl groups and could possibly alter the redox potential of cells. Several transcription factors are already known to require a reduced state to be functional (Abate et al. 1990; Xanthoudakis and Curran 1992). One can hypothesize that one or several of these transcription factors may be rendered nonfunctional by alkylation in Fah-deficient animals. Further experiments, which will assess the redox state of Fah-deficient liver cells and address the effects of reducing agents on the phenotype, will be required to resolve these questions.

\section{The phenotypes of Fah deficiency in mice and humans are different}

The phenotypes of Fah deficiency in humans and mice are rather different. The most striking difference is the short life span of affected mice. This is not explained by more mild mutations in $\mathrm{HTl}$ patients. Several reports indicate that most tyrosinemic patients have null alleles (Phaneuf et al. 1992). In addition, Fah-deficient mice are not tyrosinemic (i.e. they do not have elevations of plasma tyrosine) and human HT1 patients do not suffer from hypoglycemia. Preliminary results in human HT1 patients (R. Tanguay, pers. comm. and M. Grompe, unpubl.) indicate that disregulation of alf/hsdr-1-dependent mRNAs is not a major factor in the pathophysiology of human tyrosinemia.

To find major differences in phenotypes between humans and mice deficient in the same gene product is hardly a new phenomenon (Wu and Melton 1993). In the case of Fah deficiency, several possible explanations come to mind. First, the flux of metabolites through the tyrosine degradation pathway may be quantitatively very different in the two species. Thus, it is possible, that the different phenotypes are explained by higher levels of toxic metabolites in the mouse liver. Second, mouse hepatocytes may be more sensitive to MAA and FAA. Mouse cells may be more dependent on a transcription factor that is susceptible to alkylation. Alternatively, the potential to buffer the effects of alkylating compounds with reducing agents such as glutathione may be lower in newborn mice. It is theoretically also possible that Fah uses yet-unidentified substrates in the mouse and that it is the accumulation of compounds other than FAA and MAA that cause the hepatic dysfunction. Fah is known to utilize several other diketo acids in vitro (Hsiang et al. 1972). This question will be answerable by specifically disrupting the tyrosine catabolic pathway upstream to Fah in our mice. This could be achieved either pharmacologically by inhibiting $\mathrm{p}-\mathrm{OH}$ phenylpyruvate dioxygenase using NTBC (Lindstedt et al.
1992) or by breeding Fah-deficient animals with a recently described strain of mice deficient in that enzyme (Endo et al. 1991).

Despite the differences in phenotype, the Fah-deficient mouse strain described here can be used as an improved disease model for some aspects of human HT1. Because all phenotypic effects can be clearly attributed to Fah deficiency alone, therapeutic effects of drugs and diets can be assessed more clearly in this background. This is especially important, if such interventions lead to a prolonged survival, because the effects of deficiencies of other genes in the deletion may then be seen.

\section{Materials and methods \\ Construction of the replacement vector}

A $\lambda$ DASH II/ 129 mouse genomic library was screened with the full-length mouse Fah cDNA (Grompe and Al-Dhalimy 1992). Phages mFah 6 and 15 containing the $5^{\prime}$ end of the gene were characterized further by restriction mapping and probing with partial cDNA probes. A map of $\mathrm{mFah}$ phage 15 is shown in figure $2 \mathrm{~A}$. A $6.5-\mathrm{kb}$ EcoRV-NotI fragment from the $3^{\prime}$ end of $\mathrm{mFah} 15$ was cloned into pBluescript, and a unique $S p h I$ site was found to be located $5 \mathrm{~kb}$ from the $5^{\prime}$ and $1.5 \mathrm{~kb}$ from the $3^{\prime}$ end. DNA sequencing confirmed that this SphI site was located within a 91-bp exon and corresponded to the unique SphI site found in the cDNA. A neo expression cassette, pol2Sneo (Soriano et al. 1991), was inserted into this site, and an HSV TK expression cassette (PGKTK) (Soriano et al. 1991) was cloned into the SacII site at the $3^{\prime}$ end of the homology, creating the replacement vector $\mathrm{pDl0}$ (Fig. 2).

\section{Generation of mice with a targeted mutation in the Fah gene}

Culture and electroporation of AB1 ES cells were as described previously (Soriano et al 1991). DNA was prepared from individual clones, digested with HindIII and Southern blotted (Ramírez-Solis et al. 1992) using probe A (see Fig. 2). Blastocyst injections were as described previously (Bradley 1987).

\section{PCR genotyping}

Three PCR primers were designed. Primers A and B were located $5^{\prime}$ and $3^{\prime}$ to exon 5 of the Fah gene, respectively. Primer C was located at the $3^{\prime}$ end of the pol2Sneo expression cassette within the bovine growth hormone polyadenylation sequence. For genotyping, PCR (Mullis and Faloona 1987) was carried out with all three primers simultaneously on $200 \mathrm{ng}$ of tail-cut DNA (Miller et al. 1988). The wild-type fragment produced by use of primers $A$ and $B$ was $180 \mathrm{bp}$, and the mutant fragment with primers $C$ and B was $240 \mathrm{bp}$. Primer sequences were A, 5'-CTAGGTCAATGGCTGTTTGG-3'; B, 5'-GGACATACCAATTTGGCAAC- $3^{\prime}$; and C, 5'-TAAAATGAGGAAATTGCATCG-3'. The amplification conditions were $94^{\circ} \mathrm{C}$ for $5 \mathrm{~min}$, followed by 31 cycles of $90^{\circ} \mathrm{C}$ for $30 \mathrm{sec}, 56^{\circ} \mathrm{C}$ for $30 \mathrm{sec}$, and $72^{\circ} \mathrm{C}$ for $50 \mathrm{sec}$ in a previously described buffer (Kogan et al. 1987).

\section{Histology and electron microscopy}

Electron microscopy was performed on tissues fixed in buffered formalin. The samples were then postosmicated, embedded in araldite, sectioned on an AO-Reichert ultracut $\mathrm{E}$ microtome, and stained with uranyl acetate and lead citrate. Sections were 
examined in a Joel $100-\mathrm{CX}$ microscope at magnifications ranging from 800 to $12,000 \times$.

\section{Biochemical analysis}

Samples from animals were obtained as follows. The pups were sacrificed by decapitation, and blood was collected by dabbing the wound onto Parafilm. For anticoagulation, the blood was mixed immediately with $1 \mu \mathrm{l}$ of $500 \mathrm{~mm}$ EDTA using a Pipetman. The red blood cells were removed by a brief centrifugation, and the plasma was frozen at $-80^{\circ} \mathrm{C}$ until PCR genotyping was completed. Next, the liver was removed and also frozen at $-80^{\circ} \mathrm{C}$.

\section{Fah enzyme assay}

Fah enzyme assays were carried out at $30^{\circ} \mathrm{C}$ on a cytosolic fraction of homogenized liver as described previously by Knox (Knox and Edwards 1955). FAA, the substrate for the assay, is not commercially available and was prepared from homogentisic acid as described in the same reference. Protein concentrations were measured with a Bio-Rad kit (Bradford 1976).

\section{Blood glucose measurements}

Plasma glucose concentrations were determined by a coupled hexokinase/G-6P dehydrogenase assay (Bondar and Mead 1974) with commercially available reagents (Sigma).

\section{AST and creatinine measurements}

Twenty microliters of plasma was mixed with $80 \mu \mathrm{l}$ of a solution of $7 \%$ bovine senum albumin and assayed for AST and creatinine levels with a Kodak Ektachem 700 chemistry analyzer.

\section{Quantitative amino acid analysis}

Individual plasma samples of $25 \mu \mathrm{l}$ were quantitated on a Beckman 6300 automated amino acid analyzer (Sturman and Applegarth 1985).

\section{Organic acid analysis}

Mouse liver $(20-50 \mathrm{mg}$ ) was homogenized in $0.8 \mathrm{ml}$ of methanol and centrifuged at $12,000 \mathrm{~g}$ for $5 \mathrm{~min}$. The supernatant was removed and diluted to $5 \mathrm{ml}$ with HPLC grade water. Pooled plasma samples $(100 \mu l)$ were diluted with $4.5 \mathrm{ml}$ of water and then treated identically to the liver samples. The diluted samples were oximated for $1 \mathrm{hr}$ with $100 \mathrm{mg}$ of hydroxylamine hydrochloride at room temperature and at $\mathrm{pH}>12$. The mixture was then acidified with $\mathrm{HCl}$ to $\mathrm{pH} 1$, poured onto a liquid/ liquid extraction column (Varian Chem Elut CE 1005), and extracted with ethylacetate. The extracts were dried under nitrogen and derivatized with $25 \mu \mathrm{l}$ of $\mathrm{N}$, O-bis(trimethisilyl) trifluoroacetamide $+1 \%$ trimethylchlorosilane (Pierce) at $85^{\circ} \mathrm{C}$ for $20 \mathrm{~min}$. The sample was loaded onto a Hewlett-Packard 5890 GC/5970 mass spectroscopy instrument operating in the selected ion monitoring mode. The ions monitored were of masses $110,138,182,212$, and 227 for the two closely eluting methyl isoxazole propionate derivatives of oximated SA (Tuchman et al. 1984). A control sample was prepared in parallel but was spiked with $0.12 \mu \mathrm{g}$ of SA at the beginning of the procedure. The detection limit for SA in liver homogenate was $1 \mathrm{ng} / \mathrm{mg}$ wet, weight and for plasma it was $0.1 \mu \mathrm{g} / \mathrm{ml}$.

\section{Northern blots}

Total cellular RNA was isolated from frozen liver by the RNAzol method (Chomczynski and Sacchi 1987). Poly(A) RNA was prepared using a Polytract System III kit (Promega). Ten micrograms (total cellular RNA) or $250 \mathrm{ng}$ (poly(A) RNA) of RNA was electrophoresed through a formaldehyde gel (Sambrook et al. 1989) and transferred onto Hybond $\mathrm{N}^{+}$membrane (Amersham). Equal amounts of either total cellular RNA or poly(A) RNA were loaded into each lane. The equal loading was confirmed by reprobing each of the blots with tubulin. Hybridization was at $42^{\circ} \mathrm{C}$ in $6 \times$ SSPE, $5 \times$ Denhardt's solution, $0.5 \%$ SDS, and $50 \%$ formamide. The probes used are described in the following references: Fah (Grompe and Al-Dhalimy 1992); murine PEPCK (Lem et al. 1988); TAT (Lem et al. 1988); AS (Surh et al. 1991); OTC (Veres et al. 1987); NMO-1 (Ruppert et al. 1990); al-AT (Sifers et al. 1990); OAT (kindly provided by D. Valle, Johns Hopkins University, Baltimore, MD); and albumin (Lem et al. 1988); and tubulin (Lem et al. 1988). The murine CHOP (Ron and Habener 1992) and human $\alpha F P$ probes (Gibbs et al. 1987) were generated by PCR based on published sequences.

\section{Acknowledgments}

This work was supported by National Institute of Child Health and Human Development (NICHHD) grant HD28585-01 and a Basil O'Connor Award by The March of Dimes Foundation (M.G.), and by grants from NICHD to P.S. We thank M. Thayer, $R$. Tanguay, and $M$. Low for critically reviewing the manuscript. We also thank T. Tzounopoulos for assistance with the Northern blots and R. Mettenbrink for performing the amino acid analysis.

The publication costs of this article were defrayed in part by payment of page charges. This article must therefore be hereby marked "advertisement" in accordance with 18 USC section 1734 solely to indicate this fact.

\section{References}

Abate, C., L. Patel, F.J.3. Rauscher, and T. Curran. 1990. Redox regulation of fos and jun DNA-binding activity in vitro. Science 249: 1157-1161.

Bondar, R.J. and D.C. Mead. 1974. Evaluation of glucose-6-phosphate dehydrogenase from Leuconostoc mesenteroides in the hexokinase method for determining glucose in serum. Clin. Chem. 20: 586-590.

Bradford, M.M. 1976. A rapid and sensitive method for the quantitation of microgram quantities of protein utilizing the principle of protein-dye binding. Anal. Biochem. 72: 248254.

Bradley, A. 1987. Production and analysis of chimaeric mice. In Teratocarcinomas and embryonic stem cells. A practical approach, (ed. E. J. Robertson), pp. 113-151. IRL Press, Oxford, U.K.

Chomczynski, P. and N. Sacchi. 1987. Single-step method of RNA isolation by acid guanidinium thiocyanate-phenolchloroform extraction. Anal. Biochem. 162: 156-159.

Collins, J.C., D.N. Buchanan, J.G. Thoene, R.P. Erickson, S.S. Brooks, and S. Gluecksohn-Waelsch. 1992. Metabolic studies in a mouse model of hepatorenal tyrosinemia: Absence of perinatal abnormalities. Biochem. Biophys. Res. Commun. 187: 340-346.

DeFranco, D., S.M. Morris Jr., C.M. Leonard, and S. Gluecksohn-Waelsch. 1988. Metallothionein mRNA expression in mice homozygous for chromosomal deletions around the al- 
bino locus. Proc. Natl. Acad. Sci. 85: 1161-1164.

Edwards, M.A., A. Green, A. Colli, and G. Rylance. 1987. Tyrosinaemia type I and hypertrophic obstructive cardiomyopathy. Lancet 1: 1437-1438.

Endo, F., H. Kathoh, S. Yamamoto, and I. Matsuda. 1991. A murine model for type III tyrosinemia: Lack of immunologically detectable 4-hydroxyphenylpyruvic acid dioxygenase enzyme protein in a novel mouse strain with hypertyrosinemia. Am. J. Hum. Genet. 48: 704-709.

Fornace, A.J. Jr., D.W. Nebert, M.C. Hollander, J.D. Luethy, M. Papathanasiou, J. Fargnoli, and N.J. Holbrook. 1989. Mammalian genes coordinately regulated by growth arrest signals and DNA-damaging agents. Mol. Cell. Biol. 9: 4196-4203.

Gibbs, P.E., R. Zielinski, C. Boyd, and A. Dugaiczyk. 1987. Structure, polymorphism, and novel repeated DNA elements revealed by a complete sequence of the human alphafetoprotein gene. Biochemistry 26: 1332-1343.

Gluecksohn-Waelsch, S. 1979. Genetic control of morphogenetic and biochemical differentiation: Lethal albino deletions in the mouse. Cell 16: 225-237.

Gluecksohn-Waelsch, S. and D. DeFranco. 1991. Lethal chromosomal deletions in the mouse, a model system for the study of development and regulation of postnatal gene expression. BioEssays 13: 557-561.

Gluecksohn-Waelsch, S., M.B. Schiffman, J. Thorndike, and C.F. Cori. 1974. Complementation studies of lethal alleles in the mouse causing deficiencies of glucose-6-phosphatase, tyrosine aminotransferase, and serine dehydratase. Proc. Natl. Acad. Sci. 71: 825-829.

Goldsmith, L.A. and C. Laberge. 1989. Tyrosinemia and related disorders. In The metabolic basis of inherited disease, 6th ed. (eds. C.R. Scriver, A.L. Beaudet, W. Sly, and D. Valle), pp. 547-562. MacGraw-Hill, New York.

Gonzalez, F.J., S.Y. Liu, C.A. Kozak, and D.W. Nebert. 1990. Decreased Hnf-1 gene expression in mice homozygous for a 1.2-centiMorgan deletion on chromosome 7. DNA Cell Biol. 9: 771-776.

Grenier, A. and A. Lescault. 1985. Succinylacetone. In Methods of enzymatic analysis, (ed. H.U. Bergmeyer), pp. 79. VCH Verlagsgesellschaft, Weinheim, Germany.

Grompe, M. and M. Al-Dhalimy. 1992. Nucleotide sequence of a cDNA encoding murine fumarylacetoacetate hydrolase. Biochem. Med. Metab. Biol. 48: 26-31.

Hsiang, H.H., S.S. Sim, D.J. Mahuran, and D.E. Schmidt, Jr. 1972. Purification and properties of a diketo acid hydrolase from beef liver. Biochemistry 11: 2098-2102.

Kelsey, G. and G. Schütz. 1993. Lessons from lethal albino mice. Curr. Opin. Genet. Dev. 3: 259-264.

Kelsey, G., A. Schedl, S. Ruppert, L. Niswander, T. Magnuson, M.L. Klebig, E.M. Rinchik, and G. Schütz. 1992. Physical mapping of the albino-deletion complex in the mouse to localize alf/hsdr-1, a locus required for neonatal survival. Genomics 14: 275-287.

Klebig, M.L., L.B. Russell, and E.M. Rinchik. 1992. Murine fumarylacetoacetate hydrolase ( $\mathrm{Fah}$ ) gene is disrupted by a neonatally lethal albino deletion that defines the hepatocytespecific developmental regulation 1 (hsdr-1) locus. Proc. Natl. Acad. Sci. 89: 1363-1367.

Knox, W.E. and S.W. Edwards. 1955. Enzymes involved in conversion of tyrosine to acetoacetate. Methods Enzymol. 2: 287-300.

Kogan, S.C., M. Doherty, and J. Gitschier. 1987. An improved method for prenatal diagnosis of genetic diseases by analysis of amplified DNA sequences: Application to hemophilia A. N. Engl. J. Med. 317: 985-990.

Kvittingen, E.A. 1986. Hereditary tyrosinemia type I-an over- view. Scand. J. Clin. Lab. Invest. Suppl. 184: 27-34.

Lem, J., A.C. Chin, M.J. Thayer, R.J. Leach, and R.E. Fournier. 1988. Coordinate regulation of two genes encoding gluconeogenic enzymes by the trans-dominant locus Tse-1. Proc. Natl. Acad. Sci. 85: 7302-7306.

Lindblad, B., S. Lindstedt, and G. Steen. 1977. On the enzymic defects in hereditary tyrosinemia. Proc. Natl. Acad. Sci. 74: 4641-4645.

Lindstedt, S., E. Holme, E.A. Lock, O. Hjalmarson, and B. Strandvik. 1992. Treatment of hereditary tyrosinaemia type I by inhibition of 4-hydroxyphenylpyruvate dioxygenase. Lancet 340: 813-817.

Loose, D.S., P.A. Shaw, K.S. Krauter, C. Robinson, S. Englard, R.W. Hanson, and S. Gluecksohn-Waelsch. 1986. Trans regulation of the phosphoenolpyruvate carboxykinase (GTP) gene, identified by deletions in chromosome 7 of the mouse. Proc. Natl. Acad. Sci. 83: 5184-5188.

McKnight, S.L., M.D. Lane, and S. Gluecksohn-Waelsch. 1989. Is CCAAT/enhancer-binding protein a central regulator of energy metabolism? Genes \& Dev. 3: 2021-2024.

Miller, S.A., D.D. Dykes, and H.F. Polesky. 1988. A simple salting out procedure for extracting DNA from human nucleated cells. Nucleic Acids Res. 16: 1215.

Mitchell, G., J. Larochelle, M. Lambert, J. Michaud, A. Grenier, H. Ogier, M. Gauthier, J. Lacroix, M. Vanasse, A. Larbrisseau, K. Paradis, A. Weber, Y. Lefevre, S. Melançon, and L. Dallaire. 1990. Neurologic crises in hereditary tyrosinemia. N. Engl. J. Med. 322: 432-437.

Morris, S.M. Jr., C.L. Moncman, D.M. Kepka, V.L. Nebes, W.F. Diven, G.J. Dizikes, S.D. Cederbaum, and D. DeFranco. 1988. Effects of deletions in mouse chromosome 7 on expression of genes encoding the urea-cycle enzymes and phosphoenolpyruvate carboxykinase (GTP) in liver, kidney, and intestine. Biochem. Genet. 26: 769-781.

Mullis, K.B. and F.A. Faloona. 1987. Specific synthesis of DNA in vitro via a polymerase-catalyzed chain reaction. Methods Enzymol. 155: 335-350.

Niswander, L., G. Kelsey, A. Schedl, S. Ruppert, S.K. Sharan, K.B. Holdener, E.M. Rinchik, J.E. Edstrom, and T. Magnuson. 1991. Molecular mapping of albino deletions associated with early embryonic lethality in the mouse. Genomics 9: $162-169$.

Petersen, D.D., F.J. Gonzalez, V. Rapic, C.A. Kozak, J.Y. Lee, J.E. Jones, and D.W. Nebert. 1989. Marked increases in hepatic $\mathrm{NAD}(\mathrm{P}) \mathrm{H}$ :oxidoreductase gene transcription and mRNA levels correlated with a mouse chromosome 7 deletion. Proc. Natl. Acad. Sci. 86: 6699-6703.

Phaneuf, D., M. Lambert, R. Laframboise, G. Mitchell, F. Lettre, and R.M. Tanguay. 1992. Type 1 hereditary tyrosinemia. Evidence for molecular heterogeneity and identification of a causal mutation in a French Canadian patient. I. Clin. Invest. 90: 1185-1192.

Ramírez-Solis, R., J. Rivera-P'erez, J.D. Wallace, M. Wims, H. Zheng, and A. Bradley. 1992. Genomic DNA microextraction: A method to screen numerous samples. Anal. Biochem. 201: 331-335.

Rinchik, E.M. and L.B. Russell. 1990. Germ-line deletion mutations in the mouse: Tools for intensive functional and physical mapping of regions in the mammalian genome. In Genetic and physical mapping. Genome analysis (eds. K.E. Davies and S.M. Tilghman), pp. 121-158. Cold Spring Harbor Laboratory Press, Cold Spring Harbor, New York.

Ron, D. and J.F. Habener. 1992. CHOP, a novel developmentally regulated nuclear protein that dimerizes with transcription factors $\mathrm{C} / \mathrm{EBP}$ and LAP and functions as a dominant-negative inhibitor of gene transcription. Genes \& Dev. 6: 439- 
453.

Ruppert, S., M. Boshart, F.X. Bosch, W. Schmid, R.E.K. Fournier, and G. Schütz. 1990. Two genetically defined trans-acting loci coordinately regulate overlapping sets of liver-specific genes. Cell 61: 895-904.

Ruppert, S., G. Kelsey, A. Schedl, E. Schmid, E. Thies, and G. Schütz. 1992. Deficiency of an enzyme of tyrosine metabolism underlies altered gene expression in newborn liver of lethal albino mice. Genes \& Dev. 6: 1430-1443.

Russell, L.B., W.L. Russell, and E.M. Kelly. 1979. Analysis of the albino-locus region of the mouse. Origin and viability. $G e$ netics 91: 127-139.

Russo, P. and S. O'Regan. 1990. Visceral pathology of hereditary tyrosinemia type I. Am. J. Hum. Genet. 47: 317-324.

Sala-Trepat, J.M., M. Poiret, C.H. Sellem, R. Bessada, T. Erdos, and S. Gluecksohn-Waelsch. 1985. A lethal deletion on mouse chromosome 7 affects regulation of liver cell-specific functions: Posttranscriptional control of serum protein and transcriptional control of aldolase B synthesis. Proc. Natl. Acad. Sci. 82: 2442-2446.

Sambrook, J., E.F. Fritsch, and T. Maniatis (eds). 1989. Molecular cloning: A laboratory manual, 2nd ed. Cold Spring Harbor Laboratory Press, Cold Spring Harbor, New York.

Sassa, S. and A. Kappas. 1982. Succinylacetone inhibits deltaaminolevulinate dehydratase and potentiates the drug and steroid induction of delta-aminolevulinate synthase in liver. Trans. Assoc. Am. Physicians 95: 42-52.

- 1983. Hereditary tyrosinemia and the heme biosynthetic pathway. Profound inhibition of delta-aminolevulinic acid dehydratase activity by succinylacetone. J. Clin. Invest. 71: 625-634.

Schmid W., G. Müller, G. Schütz, and S. Gluecksohn-Waelsch. 1985. Deletions near the albino locus on chromosome 7 of the mouse affect the level of tyrosine aminotransferase mRNA. Proc. Natl. Acad. Sci. 82: 2866-2869.

Sifers, R.N., F.D. Ledley, L. Reed-Fourquet, D.H. Ledbetter, S.A. Ledbetter, and S.L. Woo. 1990. Complete cDNA sequence and chromosomal localization of mouse alpha 1-antitrypsin. Genomics 6: 100-104.

Soriano, P., C. Montgomery, R. Geske, and A. Bradley. 1991. Targeted disruption of the c-src proto-oncogene leads to osteopetrosis in mice. Cell 64: 693-702.

Stoner, E., H. Starkman, D. Wellner, V.P. Wellner, S. Sassa, A.B. Rifkind, A. Grenier, P.G. Steinherz, A. Meister, M.I. New et al. 1984. Biochemical studies of a patient with hereditary hepatorenal tyrosinemia: Evidence of glutathione deficiency. Pediatr. Res. 18: 1332-1336.

Sturman, J.A. and D.A. Applegarth. 1985. Automated amino acid analysis. In Neuromethods (eds. A.A. Boulton, G.B. Baker, and J.D. Wood), pp. 1-27. Humana Press, Inc., Clifton, NI.

Surh, L.C., A.L. Beaudet, and W.E. O'Brien. 1991. Molecular characterization of the murine argininosuccinate synthetase locus. Gene 99: 181-189.

Tanguay, R.M., C. Laberge, A. Lescault, J.P. Valet, J.L. Duband, and Y. Quenneville. 1984. Molecular basis of hereditary tyrosinemia: Proof of the primary defect by Western blot. In Advances in gene technology: Human genetic disorders (ed. F. Ahmad, S. Black, J. Schultz, W.A. Scott, and W.J. Whelan), pp. 256-257. Cambridge University Press, Cambridge, UK.

Tönjes R.R., K.G. Xanthopoulos, J.E.J. Darnell, and D. Paul. 1992. Transcriptional control in hepatocytes of normal and $\mathrm{c}^{14 C o S}$ albino deletion mice. EMBO F. 11: 127-133.

Tuchman, M., C.B. Whitley, M.L. Ramnarain, L.D. Bowers, K.D. Fregien, and W. Krivit. 1984. Determination of urinary succinylacetone by capillary gas chromatography. I. Chro- matog. Sci. 22: 211-215.

Tuchman, M., D.K. Freese, H.L. Sharp, C.B. Whitley, M.L. Ramnaraine, R.A. Ulstrom, J.S. Najarian, N. Ascher, N.R. Buist, and A.B. Terry. 1985. Persistent succinylacetone excretion after liver transplantation in a patient with hereditary tyrosinaemia type I. J. Inherit. Metab. Dis. 8: 21-24.

Veres, G., R.A. Gibbs, S.E. Scherer, and C.T. Caskey. 1987. The molecular basis of the sparse fur mouse mutation. Science 237: 415-417.

$\mathrm{Wu}$, C.L. and D.W. Melton. 1993. Production of a model for Lesch-Nyhan syndrome in hypoxanthine phosphoribosyltransferase-deficient mice. Nat. Genet. 3: 235-240.

Xanthoudakis, S. and T. Curran. 1992. Identification and characterization of Ref-1, a nuclear protein that facilitates AP-1 DNA-binding activity. EMBO I. 11: 653-665. 


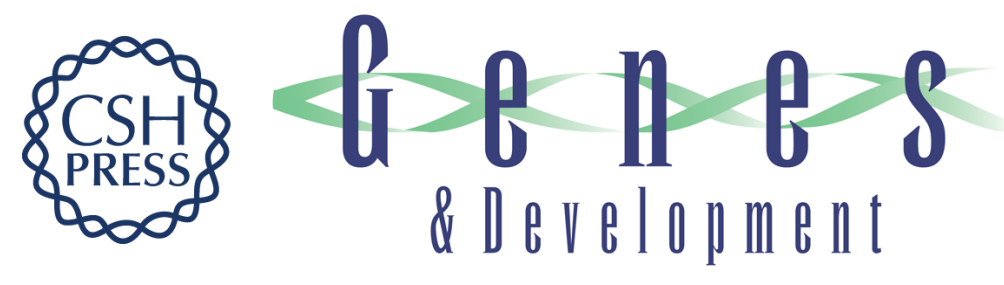

\section{Loss of fumarylacetoacetate hydrolase is responsible for the neonatal hepatic dysfunction phenotype of lethal albino mice.}

M Grompe, M al-Dhalimy, M Finegold, et al.

Genes Dev. 1993, 7:

Access the most recent version at doi:10.1101/gad.7.12a.2298

References This article cites 54 articles, 17 of which can be accessed free at:

http://genesdev.cshlp.org/content/7/12a/2298.full.html\#ref-list-1

License

Email Alerting

Receive free email alerts when new articles cite this article - sign up in the box at the top

Service right corner of the article or click here.

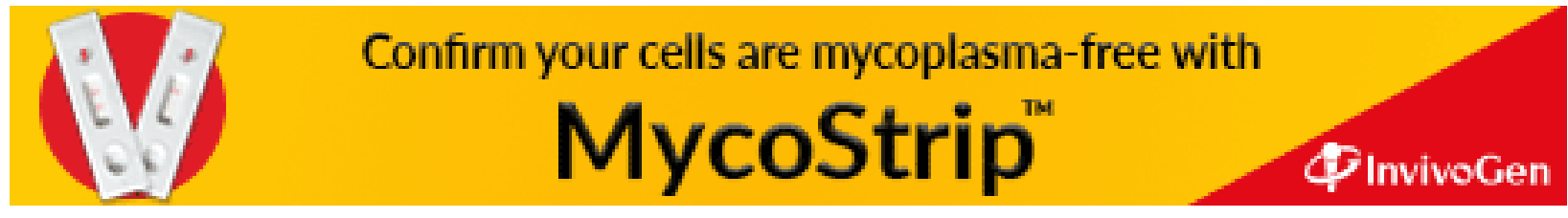

